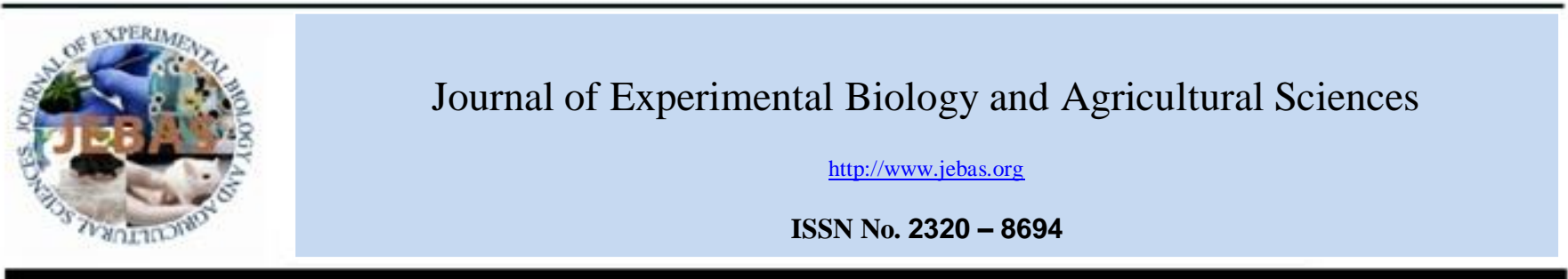

\title{
ISOLATION AND CHARACTERIZATION OF PLANT GROWTH PROMOTING POTENTIAL OF Acinetobacter $s p$. RSC7 ISOLATED FROM Saccharum officinarum cultivar Co 671
}

\author{
Prittesh Patel ${ }^{1 *}$, Rushabh Shah ${ }^{1}$, Krunal Modi ${ }^{2}$
}

${ }^{1}$ CG Bhakta Institute of Biotechnology, Uka Tarsadia University, Bardoli, 394350 - Gujarat, India

${ }^{2}$ ASPEE SHAKILAM Agricultural Biotechnology Institute, Navsari Agricultural University, Surat, Gujarat, India

Received - June 16, 2017; Revision - August 30, 2017; Accepted - September 02, 2017

Available Online - September 10, 2017

DOI: http://dx.doi.org/10.18006/2017.5(4).483.491

\section{KEYWORDS}

Acinetobacter

Indole Acetic Acid

PGPR

Phosphate

Sugarcane

\section{ABSTRACT}

Genus Acinetobacter can be exploiting as an ecofriendly plant-growth promoting rhizobacteria and as an alternative to chemical fertilizers. In present study, Acinetobacter strain RSC7 isolated from the rhizosphere of sugarcane cultivar Co671 has been used for the characterization of plant growth potential and molecular identification through 16S rRNA gene sequence. The phosphate solubilisation Index (SI) of the isolate strain was tested on the Pikovskaya agar and recorded 3.5 and quantitative estimation of isolated strain revealed that maximum $27.10 \mu \mathrm{g} / \mathrm{ml}$ phosphate was releases in NBRIP broth with $1.5 \%$ tricalcium phosphate after $120 \mathrm{hr}$ incubation at $37^{\circ} \mathrm{C}$. Further, IAA production was also estimated and it was reported $20.89 \mu \mathrm{g} / \mathrm{ml}$ after $24 \mathrm{hr}$ and within $48 \mathrm{hr}$ production significantly increase to $43.85 \mu \mathrm{g} / \mathrm{ml}$. Acinetobacter strain has potential to act as plant-growth promoting rhizobacteria and can enhance the growth of Vigna radiate, Vigna unguiculata, Abelmoschus esculentus, Dolichos lablab. The improved seedling growth parameters of the treated crop seeds indicated the potential of Acinetobacter sp. RSC7 to be used in a bio-fertilizer formulation for sustainable production.
* Corresponding author

E-mail: pritteshpatel@gmail.com (Prittesh Patel)

Peer review under responsibility of Journal of Experimental Biology and Agricultural Sciences.

Production and Hosting by Horizon Publisher India [HPI] (http://www.horizonpublisherindia.in/).

All rights reserved.
All the article published by Journal of Experimental Biology and Agricultural Sciences is licensed under a Creative Commons Attribution-NonCommercial 4.0 International License Based on a work at www.jebas.org.

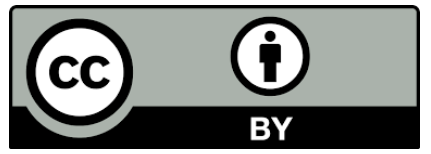




\section{Introduction}

Although Chemical fertilizer gives higher crop productivity but their prolong and overuse makes the soil less fertile and unsuitable for agriculture. Continues deposition of chemicals also leads the environmental and health hazard. On flipside, the rhizosphere is a unique locus, which is associated with various groups of microorganisms those have capacity to influence plant growth beneficially. So, the best alternative approach for sustainable cultivation is to use of such plant growth promoting rhizobacteria (PGPR). Rhizobacteria that exert affirmative effects on plant development are called PGPR (Bashan \& Holguin, 1998; Chaiharn et al., 2008) and are use to increasing seed germination (Reed et al., 2005; Lytvynenko et al., 2006) or stimulating the development of seedling roots (Patten \& Glick, 2002b), or indirectly by inhibiting phytopathogens (Haas \& Défago, 2005). The concept of PGPR for promotion of plant growth is gaining worldwide acceptance (Zablotowicz et al., 1991). The beneficial effects of PGPR have been demonstrated in many crops, but practical implementation in field requires to detailed research on various factors like limited self life, variability of environmental conditions and plant species (Mendes et al., 2013). Recently Modi $\&$ Patel (2017) reported six potential PGPR isolates from different sugarcane cultivars.

In recent years, members of the genus Acinetobacter have been isolated from the rhizosphere of different plants (RokhbakhshZamin et al., 2011; Kuan et al., 2016). In this context, there is some evidence that Acinetobacter strains play an important role in plant- growth promotion (Huddedar et al., 2002; Indiragandhi et al., 2008), as certain strains of this genus are known to be involved in phytostimulation based on the production of plantgrowth-promoting hormones (Huddedar et al., 2002), solubilization of phosphate (P) (Gulati et al., 2009; Peix et al., 2009), and production of siderophores (Sarode Prashant et al., 2009). The importance of sugarcane as one of the most important commercial crop needs no special emphasis. This crop is major sources for employments and industrial development particularly in some developing countries (Mohanraj et al., 2002). It is a long duration crop and faces many biotic and abiotic challenges during developmental period, the PGPR associated with sugarcane root may be effective and functional for supporting plant growth (Bhardwaj et al., 2017). So, there has been a new focus on investigating the abilities of such bacteria to increased productivity of multiple crops, including vegetables. Sharma et al., (2003) have reported growth promotion in $V$. radiate by Pseudomonas strain GRP3. Deepa et al. (2010) reported plant growth promoting ability of Enterobacter Species from nonrhizospheric soil in $V$. unguiculata. This report explores the potential of Acinetobacter for In vitro growths promoting activities such as IAA production, phosphate solubilization, nitrogen fixation and siderophore production as well as growth promotion in $V$. radiate, $V$. unguiculata, A. esculentus, D. lablab under green house condition.

\section{Materials and Methods}

\subsection{Collection of soil sample and Isolation of bacteria}

For bacterial isolation, soil samples were collected from the rhizosphere of sugarcane plant (Saccharum officinarum) CoC671 grown in agricultural fields of the Madhi village $\left(25^{\circ} 20^{\prime} 39^{\prime \prime} \mathrm{N}\right.$ latitude and $84^{\circ} 12^{\prime} 46^{\prime \prime} \mathrm{E}$ longitude) in Surat district of Gujarat, India. Randomly selected plants were uprooted carefully and the excess of soil was removed by gentle shaking and the soil adhering to the roots formed composite samples. The collected samples were placed in sterilized plastic bags and transferred to the laboratory under temperature controlled conditions. The soil adhering to the roots was removed by gentle agitation and serially diluted in physiological saline $(0.85 \%, \mathrm{NaCl} w / v)$, spread plated in triplicate on Nutrient Agar medium and incubated at $30{ }^{\circ} \mathrm{C}$ for $48 \mathrm{~h}$. Representative colonies were selected on the basis of distinct morphological characteristics, including color of colony, texture of colony, elevation and margin; texture and opacity. After primary screening for various plant growth promoting (PGP) traits, a predominant white colony with good activity was selected and maintained on nutrient agar slants at $4{ }^{\circ} \mathrm{C}$. Isolate was also characterized for biochemical characters as method described by Cappuccino et al. (1996). All the subsequent experiments were carried out after raising fresh cultures.

\subsection{Antibiotic Susceptibility Assay}

To evaluate the antibiotic susceptibility of Acinetobacter sp. $\mathrm{RSC} 7,1 \mathrm{ml}$ of overnight grown culture was inoculated into sterile $20 \mathrm{ml}$ melted nutrient agar and poured into sterile $9 \mathrm{~mm}$ Petri plates. After the media got solidified antibiotic hexa disc (HiMedia) were placed on it and were incubated overnight at $37^{\circ} \mathrm{C}$ and clear zone of inhibition was recorded.

\subsection{Phosphate Solubilization Quantification}

The phosphate solubilization activity to the isolated bacterium was detected on Pikovskaya agar medium. For this $10 \mu \mathrm{l}$ of $24 \mathrm{hr}$ old bacterial culture was inoculated on center of media and diameter $(\mathrm{dm})$ of colony and halo zone around was measured after $48 \mathrm{hrs}$ at $37^{\circ} \mathrm{C}$ (Bashan \& Holguin, 1998). The phosphate solubilization efficiency (SE) was calculated ( $\mathrm{SE}=100 \mathrm{X}$ Diameter of Halo zone /Diameter of colony). For quantification, an actively growing $0.1 \mathrm{ml}$ of bacterial suspension was transferred to $9.9 \mathrm{ml}$ of a NBRIP broth with $0.5 \%, 1 \%$ and $1.5 \%$ Tri-calcium phosphate and incubated on shaker at $120 \mathrm{rpm}, 37^{\circ} \mathrm{C}$. Quantitative measurement was carried out according to Bhardwaj et al. (2017). 
The quantity of solubilized phosphate was determined using a standard graph and achieved using known quantities of calcium phosphate solutions and reading the absorbance at $660 \mathrm{~nm}$. Uninoculated broth was used as the blank (Pikovskaya, 1948)

\subsection{Indole Acetic Acid (IAA) Quantification}

The isolate was grown in a sterile LB broth from pure colony for $24 \mathrm{hr}$ at $30^{\circ} \mathrm{C} .0 .1 \mathrm{ml}$ of the bacterial culture was inoculated into $9.9 \mathrm{ml}$ of sterile LB medium containing $0.1 \%$ tryptophan as precursor and incubated at $30^{\circ} \mathrm{C}$. IAA production was measured after $24 \mathrm{hr}, 48 \mathrm{hr}, 72 \mathrm{hr}, 96 \mathrm{hr}$ and $120 \mathrm{hr}$ by adding $2 \mathrm{ml}$ of the Salkowaski reagent to $1 \mathrm{ml}$ of the culture supernatant. Development of a pink to red color was measured by spectrophotometer analysis at $540 \mathrm{~nm}$ (Huddedar et al., 2002).

\subsection{Nitrogen Fixation and Siderophore production}

Both Nitrogen Fixation and Siderophore production property was checked qualitatively on Jensan and CAS media respectively (Jensen, 1965; Schwyn \& Neilands, 1987).

\subsection{Molecular identification and phylogeny}

Total genomic DNA was extracted and used as DNA template in polymerase chain reaction (PCR) for amplification of the $16 \mathrm{~S}$ rDNA gene. PCR amplification was performed with primer set; 27F (5'-AGAGTTTGATCTTGGCTCAG-3') and 1492R (5'TACGGTTACCTTGTTACGACTT-3'). The amplified sequence was analyzed using the Basic Local Alignment Search Tool (BLAST) to identify the most closely related sequences from Gen Bank DNA database (www.ncbi.nlm.nih.gov). The partial 16S rDNA sequence of the strain was submitted to the NCBI database. The phylogenetic tree was constructed using MEGA 5.0 software and Kimura's two-parameter model, after aligning the sequences with ClustalW.

\subsection{Seed germination bioassay}

The seeds of Vigna radiate, $V$. unguiculata, Abelmoschus esculentus, Dolichos lablab were used for germination assay under greenhouse condition at Uka Tarsadia University. All the selected seeds were surface sterilized by $1 \% \mathrm{NaOCl}$ for $90 \mathrm{sec}$, followed by $30 \mathrm{sec}$ in $70 \%$ ethanol and two consecutive rinses in sterile distilled water, followed by air drying under laminar air flow condition (Lamy et al., 2010). Bacterial inoculum was prepared by collecting bacterial cells from $24 \mathrm{hr}$ old culture and was diluted to adjust $10^{6} \mathrm{cfu} / \mathrm{ml}$ with sterile distilled water. Seeds were coated with culture by immersion in a suspension of bacteria for $30 \mathrm{~min}$ and were then dried in a laminar flow cabinet for 1 to 2 hr. This experiment was carried out in four replications and the results were compared with that for control seeds treated with water instead of a bacterial isolate. Fifty seeds treated with bacteria and water was placed in pot containing four time autoclaved soil and was incubated for 7 days under green house condition. Germinated seeds were counted at day 7. The average plant height, root weight and lengths for each plant were also recorded for calculation of the vigour index. Vigour index (VI) was calculated by $\mathrm{VI}=(\mathrm{RL}+\mathrm{SL}) \times \mathrm{PG}($ Razmi et al., 2013).

\section{Results and Discussion}

The screening of the potent PGPR strain is appearing to be most effective strategy for improvement of agriculture crops. The present study was initiated to investigate the plant growthpromoting efficacy of cultivable rhizosphere bacteria Acinetobacter $s p$. RSC7 from the sugarcane Co 671. Preliminary identification of these isolates as members of the genus Acinetobacter was purely based on the morphological, cultural, and biochemical characteristics. The isolated bacterium was Gram-negative, motile, rod shaped with oxidase negative and catalase positive features. All the identified biochemical characters have been represented in table 1. Further, 16S rDNA sequence analysis; this bacterial strain was identified as Acinetobacter spp. The plant growth-promoting traits of the isolated Acinetobacter strain revealed that the bacteria possessed properties such as phosphate solubilization, IAA production, nitrogen fixation, and siderophore production. Acinetobacter $s p$.

Table 1: Biochemical properties of isolate RSC7

\section{Biochemical test Result}

\begin{tabular}{|ll|}
\hline Glucose & Positive \\
\hline Maltose & Negative \\
\hline Lactose & Negative \\
\hline Sucrose & Positive \\
\hline MR & Negative \\
\hline VP & Negative \\
\hline Citrate & Positive \\
\hline Catalase & Positive \\
\hline Nitrate Reduction & Positive \\
\hline Phenyl alenine & Negative \\
\hline HCN & Negative \\
\hline Amylase & Negative \\
\hline Pectinase & Negative \\
\hline Cellulase & Negative \\
\hline Protease & Negative \\
\hline Lipase & Positive \\
\hline Laccase & Negative \\
\hline
\end{tabular}


Table 2 Antibiotics susceptibility profile of Acinetobacter sp. RSC7 isolate

\begin{tabular}{|c|c|c|c|c|c|}
\hline Antibiotic & $\begin{array}{c}\text { Zone of } \\
\text { Inhibition } \\
(\mathrm{mm})\end{array}$ & Antibiotic & $\begin{array}{c}\text { Zone of } \\
\text { Inhibition } \\
(\mathrm{mm})\end{array}$ & Antibiotic & $\begin{array}{c}\text { Zone of } \\
\text { Inhibition } \\
(\mathrm{mm})\end{array}$ \\
\hline Ampicillin $10 \mu \mathrm{g}$ & 15 & Cefotaxime $30 \mu \mathrm{g}$ & 15 & Imipenem $10 \mu \mathrm{g}$ & 18 \\
\hline Ceftriaxone $30 \mu \mathrm{g}$ & 16 & Cefepime $30 \mu \mathrm{g}$ & 17 & Cloxacilin $1 \mu \mathrm{g}$ & $\mathrm{R}$ \\
\hline Chloramphenicol $30 \mu \mathrm{g}$ & 10 & Cefoperazone $75 \mu \mathrm{g}$ & 25 & Erythromycin $15 \mu \mathrm{g}$ & 20 \\
\hline Ciprofloxacin $5 \mu \mathrm{g}$ & 28 & Linezolid $30 \mu \mathrm{g}$ & $\mathrm{R}$ & Cephalexin $30 \mu \mathrm{g}$ & $\mathrm{R}$ \\
\hline Co-Trimoxazole $25 \mu \mathrm{g}$ & 22 & Gentamicin $10 \mu \mathrm{g}$ & 16 & Clavulanic acid $10 \mu \mathrm{g}$ & 20 \\
\hline Tetracycline $30 \mu \mathrm{g}$ & 22 & Vancomycin $30 \mu \mathrm{g}$ & 14 & Clindamycin $2 \mu \mathrm{g}$ & $\mathrm{R}$ \\
\hline
\end{tabular}

$\mathrm{R}$ - Resistance

RSC7 susceptibility was evaluated against 18 antibiotics and found to be sensitive to 14 antibiotics and resistant to 4 antibiotics namely Linezolid, Cloxacillin, Cephalexin and Clindamycin (Table 2).

Phosphorus is major nutrient required for the plant growth. Generally, plenty of phosphorus is available in the soil due to overuse of chemical fertilizer and it is in the insoluble mineral form. Due to accumulation of unutilized phosphorous, soil become dry and its structure change drastically. Phosphate solubilizing bacteria (PSB) play an important role in improving the availability of phosphorus to plants by converting it into soluble form and increasing the crop yield (Jones \& Darrah, 1994; Toro et al., 1997). The Acinetobacter strain was identified as

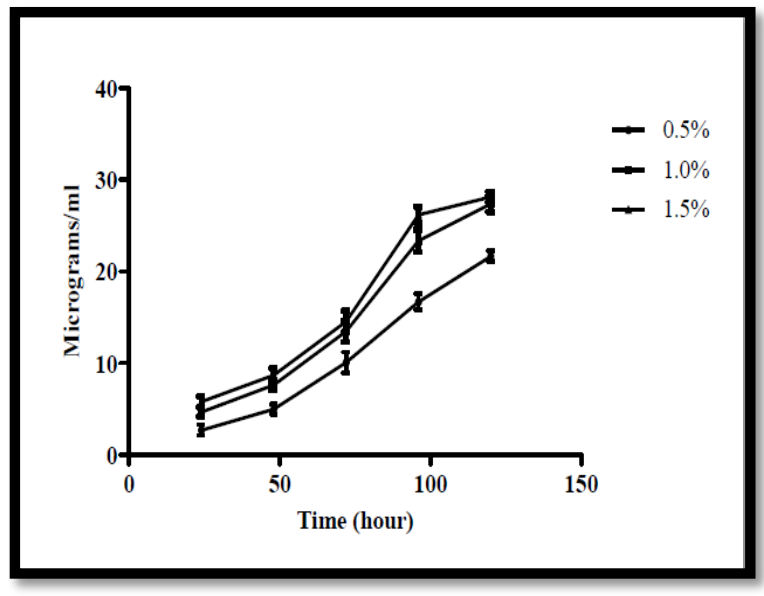

Figure 1a potential phosphate solubilizers based on its ability to solubilize tricalcium phosphate $\left[\mathrm{Ca}_{3}\left(\mathrm{PO}_{4}\right)_{2}\right]$ by formation of a clear zone of solubilization around the colony on Pikovskaya agar medium. In NBRIP broth P solubilization has been increase gradually from 24 $\mathrm{hr}$ to $120 \mathrm{hr}$ at all the three different concentrations $(0.5 \%, 1.0 \%$ and $1.5 \%$ ) of insoluble $\mathrm{P}$ supplemented studied. Significant increases from $8.869 \mu \mathrm{g} / \mathrm{ml}$ to $14.521 \mu \mathrm{g} / \mathrm{ml}$ was reported in released $\mathrm{P}$ concentration from third to fourth day in $1.5 \%$ $\mathrm{Ca}_{3}\left(\mathrm{PO}_{4}\right)_{2}$ concentration. The bacterial isolate showed maximum solubilization on the 5th day of incubation and their maximum values of P solubilized was $27.10 \mu \mathrm{g} / \mathrm{ml}$ (Figure 1). The results of study revealed that the isolate could efficiently solubilise higher concentration of $\mathrm{P}(1.5 \%)$. This indicates its potential to be use as biofertilizer for eco-friendly farming.

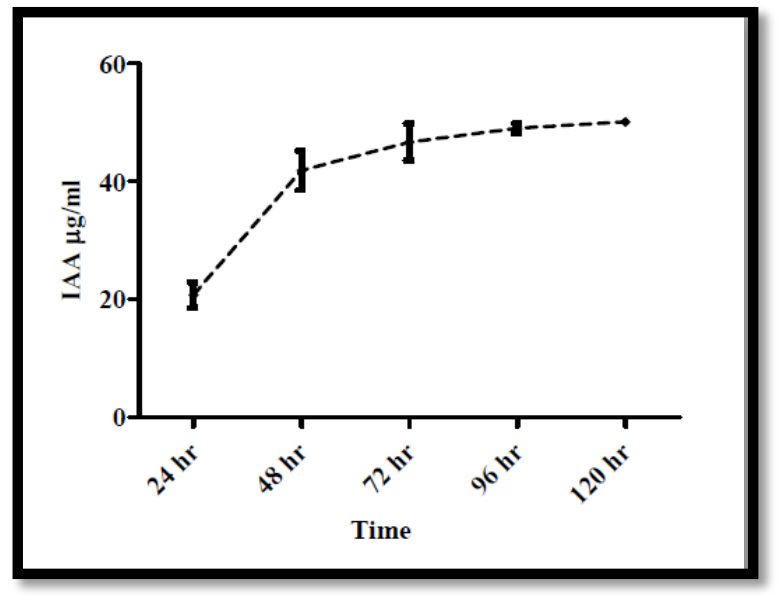

Figure1b

Figure 1a: Phosphate solubilization by Acinetobacter strain in the Pikovskya medium supplemented with different concentration of Tri-calcium phosphate on different time interval (Error bars are \pm SEM; $\mathrm{n}=3$ )

Figure 1b The IAA production of RSC7 strain in the LB medium supplemented with tryptophan at different time interval (Error bars are \pm SEM; $\mathrm{n}=3$ ). 
The Acinetobacter strain obtained in this study was further investigated for its plant hormone (IAA) production trait. The results of study indicated that L-tryptophan amended as a precursor in LB broth was converted to IAA by Acinetobacter sp. RSC7 up at more or less constant rate up to 120 hour. Initially after $24 \mathrm{hr}$, IAA production was found to be $20.89 \mu \mathrm{g} / \mathrm{ml}$ and its production reached $43.85 \mu \mathrm{g} / \mathrm{ml}$ after $48 \mathrm{hr}$. Here after, IAA production increase slowly $46.83 \mu \mathrm{g} / \mathrm{ml}, 49.66 \mu \mathrm{g} / \mathrm{ml}$ and $50.27 \mu \mathrm{g} / \mathrm{ml}$ at $72 \mathrm{hr}, 96 \mathrm{hr}$ and $120 \mathrm{hr}$ respectively. Contradictory results are reported by Swain et al. (2007), these researchers reported that IAA production increased linearly from 2 to 8 days and decreased later on with reducing the growth of organisms in L-tryptophan-supplemented medium. Results of present study are in agreement with the findings of Patten \& Glick (2002a), those who have also reported increased IAA production up to $96 \mathrm{hr}$ and attributed to the greater availability of the precursor. Datta \& Basu (2000) studied the IAA-degrading enzymes responsible for decrease in IAA production after $96 \mathrm{hr}$ incubation period. Like present investigation, various researchers also reports on the involvement of the genus Acinetobacter in the production of IAA and its effect on plant growth (Huddedar et al., 2002; Gulati et al., 2009). Therefore, the multiplication of this bacterial strain in the rhizosphere with the release of IAA may enhance plant growth. Moreover, IAA production may be an important strategy for detoxifying excess tryptophan released in the rhizosphere
(Teixeira et al., 2007). The IAA hormone not only supports the plant growth but also inhibits the mycelial germination of various pathogenic fungi (Brown \& Hamilton, 1992; Hahn \& Strittmatter, 1994).

Nitrogen fixation is considered as a direct plant growth-promoting trait and the nitrogen fixing rhizobacteria provide an alternative source to inorganic nitrogen fertilizers. In the present study, it was also reported that the isolated bacteria can efficiently grown on Jensen medium which is especially recommended for the detection and cultivation of nitrogen fixing bacteria. The siderophores of rhizobacteria can significantly influence the ability of plants to acquire iron from soil (Sarode Prashant et al., 2009). In the present study, the siderophore production by Acinetobacter species was also revealed by a CAS plate assay.

The isolate were identified at molecular level using partial $16 \mathrm{~S}$ rDNA sequence analysis. The 16S rDNA sequences of Acinetobacter sp. RSC7 determined in this study were deposited in GenBank database under accession number KX168056. The evolutionary history was inferred using the Neighbor-Joining method (Saitou \& Nei, 1987). The optimal tree with the sum of branch length $=1.06205122$ is shown (Figure 2). The percentage of replicate trees in which the associated taxa clustered together in the bootstrap test (1000 replicates) is shown next to the branches

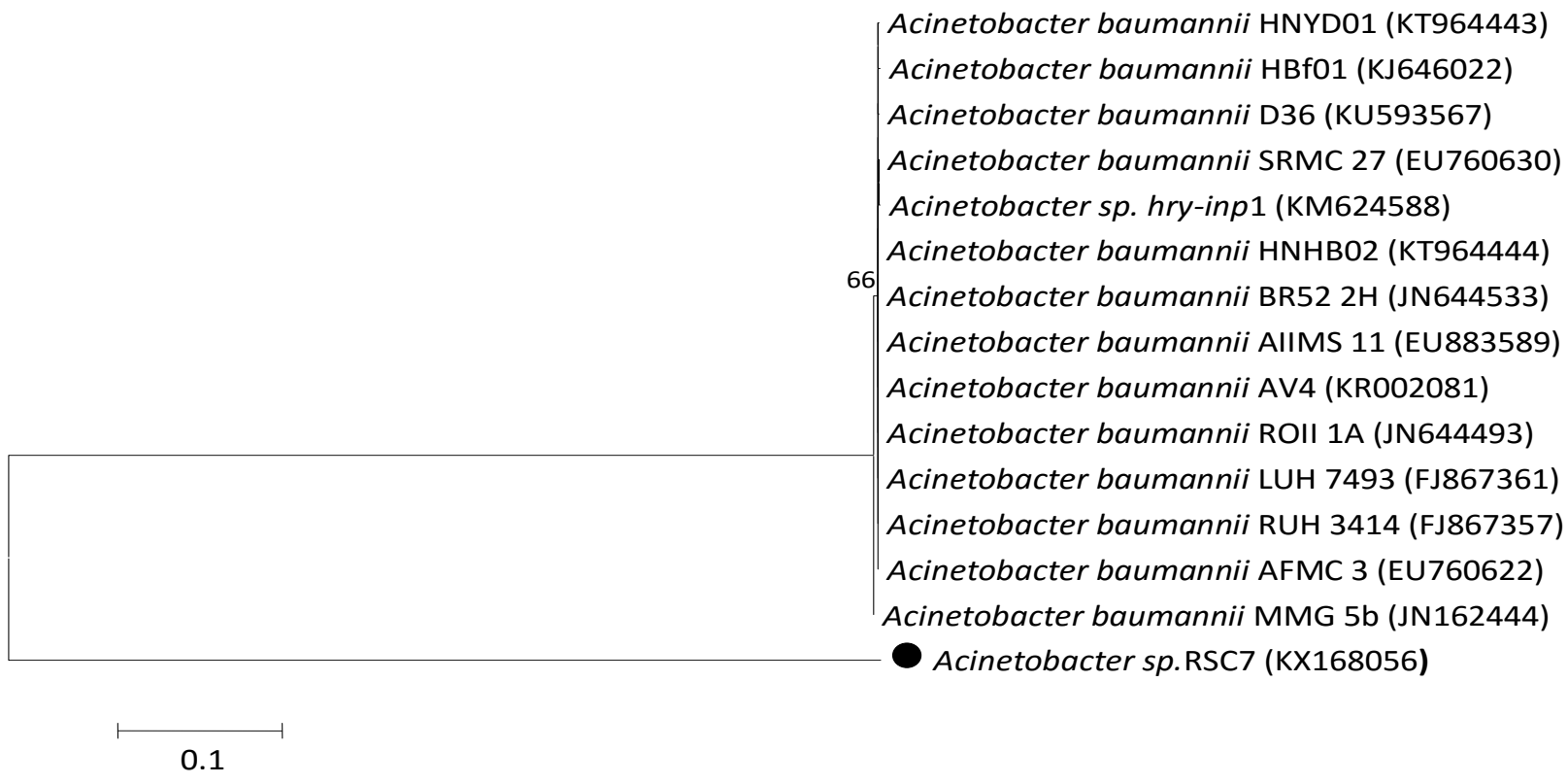

Figure 2: A neighbor-joining tree derived from sequences of $16 \mathrm{~S}$ rRNA region of Acinetobacter sp. RSC7. Numbers on nodes represent bootstrap values (\%) from 1000 replicates. A phylogenetic tree was constructed using MEGA 5.0 with kimura-two parameter model. Bar represents 0.1 substitutions per site

Journal of Experimental Biology and Agriculture Science http://www.jebas.org 
(Felsenstein, 1985). The tree is drawn to scale, with branch lengths in the same units as those of the evolutionary distances used to infer the phylogenetic tree. The evolutionary distances were computed using the Kimura 2-parameter method and are in the units of the number of base substitutions per site (Kimura, 1980). The analysis involved 15 nucleotide sequences. All positions containing gaps and missing data were eliminated. There were a total of 1421 positions in the final dataset. Evolutionary analyses were conducted in MEGA5 (Tamura et al., 2011).

The seeds are the reproductive part of the plant which is expected to give more rises in shoot and root growth upon application of PGPR. The ability of Acinetobacter sp. RSC7 to promote the growth of $V$. radiate, $V$. unguiculata, A. esculentus, and D. lablab seedlings were evaluated in pot experiments (Figure 3). Acinetobacter sp. RSC7 significantly promoted all the studied growth traits in the all plants (Tables 3). Similarly, promotion of the growth parameters of several crop plants in response to inoculation with PGPR has also been reported by other researchers (Egamberdiyeva, 2007; Sachdev et al., 2010). In studied treatment, seed germination was in the range from $91 \%$ to $97 \%$ and maximum was recorded in the pots of V. unguiculata. In case of $V$. unguiculata, plant heights increased almost double from $9.37 \pm 1.72 \mathrm{~cm}$ to $18.77 \pm 1.31$ in case of treatment (Table 3 ). As with plant height, seed treatment also had significant effect on the shoot dry weight $(103.7 \pm 9.29)$ and this was significantly different from control $(42.0 \pm 7.00 \mathrm{mg})$. Treated $V$. radiata seeds had shown the highest root length $(9.17 \pm 1.00 \mathrm{~cm})$ as compared to control $(4.17 \pm 0.25 \mathrm{~cm})$. Similar observations were made in the case of growth parameters for Abelmoschus esculentus and Dolichos lablab. The seedling vigour index of V. radiata (2522.3) was recorded maximum and it was followed by the $V$. unguiculata (2360.3) A. esculentus (2041.4), and D. lablab (2021.1). However, the present investigation revealed that Acinetobacter strains have interesting plant-growth-promoting traits, such as phosphate solubilization, IAA production, siderophore production and nitrogen fixation. Thus, the present data corroborates the hypotheses that Acinetobacter strain has the potential to act as plant-growth-promoting rhizobacteria and can enhance the growth of V. radiate, V. unguiculata, A. esculentus, D. lablab.

\section{Conclusion}

Over all, this study revealed that the plant growth- promoting traits associated with Acinetobacter strains were indicative of a beneficial relationship between the plants and the Acinetobacter strain. Thus the prevalence of Acinetobacter species with multiple plant growth-promoting traits in the rhizosphere of plants emphasizes its potential for development of effective bioinoculant to improve the growth and health of plants.

\section{Conflict of interest}

Authors would hereby like to declare that there is no conflict of interests that could possibly arise
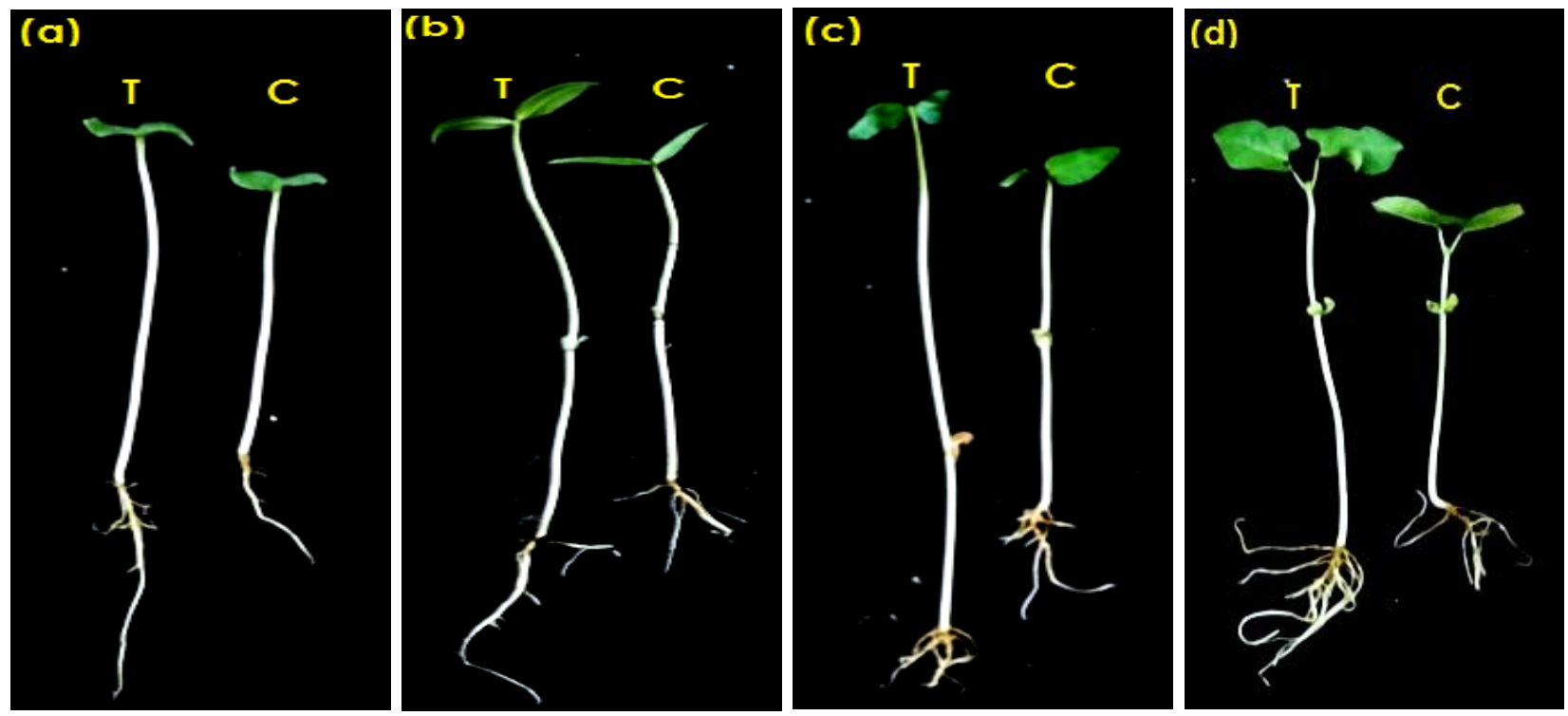

Figure 3 Effects of Acinetobacter spps. RSC7 on the growth of seedlings grown for 6 day after plantation.

(a) V. radiate (b) V. unguiculata (c) A. esculentus (d) D. lablab

Journal of Experimental Biology and Agriculture Science http://www.jebas.org 
Table 3 Effects of Acinetobacter sp RSC7 on the growth of seedlings grown for 7 days in the pot under green house condition

\begin{tabular}{|c|c|c|c|c|c|c|c|c|c|}
\hline Seed & & PG & SL & SFW & SDW & RL & RFW & RDW & VI \\
\hline \multirow{2}{*}{ Vigna radiate } & Control & 78 & $12.73 \pm 1.21$ & $282.3 \pm 37.4$ & $31.7 \pm 3.51$ & $4.17 \pm 0.25$ & $46.7 \pm 8.6$ & $13.0 \pm 3.6$ & 1318.2 \\
\hline & Treatment & 94 & $17.67 \pm 1.20$ & $457.7 \pm 39.2$ & $51.3 \pm 3.51$ & $9.17 \pm 1.00$ & $99.0 \pm 5.3$ & $25.3 \pm 4.5$ & 2522.3 \\
\hline \multirow{2}{*}{$\begin{array}{c}\text { Vigna } \\
\text { unguiculata }\end{array}$} & Control & 75 & $9.37 \pm 1.72$ & $444.3 \pm 49.2$ & $59.0 \pm 6.00$ & $3.00 \pm 0.46$ & $62.3 \pm 4.0$ & $23.7 \pm 3.8$ & 927.5 \\
\hline & Treatment & 97 & $18.77 \pm 1.31$ & $722.7 \pm 29.5$ & $78.7 \pm 6.51$ & $5.57 \pm 0.31$ & $67.7 \pm 6.5$ & $35.7 \pm 1.5$ & 2360.3 \\
\hline \multirow{2}{*}{$\begin{array}{c}\text { Abelmoschus } \\
\text { esculentus }\end{array}$} & Control & 70 & $8.80 \pm 1.05$ & $437.3 \pm 41.9$ & $42.0 \pm 7.00$ & $4.43 \pm 0.50$ & $59.3 \pm 7.5$ & $15.3 \pm 3.8$ & 926.3 \\
\hline & Treatment & 91 & $14.17 \pm 1.00$ & $566.7 \pm 33.1$ & $103.7 \pm 9.29$ & $8.27 \pm 0.70$ & $71.7 \pm 7.0$ & $48.0 \pm 4.6$ & 2041.4 \\
\hline \multirow{2}{*}{$\begin{array}{c}\text { Dolichos } \\
\text { lablab }\end{array}$} & Control & 69 & $10.27 \pm 1.16$ & $462.3 \pm 35.8$ & $87.0 \pm 8.19$ & $4.37 \pm 0.47$ & $93.7 \pm 3.5$ & $46.3 \pm 3.5$ & 1009.7 \\
\hline & Treatment & 95 & $15.23 \pm 1.88$ & $637.0 \pm 57.8$ & $128.0 \pm 4.58$ & $7.73 \pm 0.60$ & $127.0 \pm 10.5$ & $59.0 \pm 4.6$ & 2021.1 \\
\hline
\end{tabular}

PG - Percentage Germination, SL - Shoot Length, SFW - Shoot Fresh Weight, SDW - Shoot Dry Weight, RL - Root Length, RFW - Root

Fresh Weight, RDW - Root Dry Weight, VI - Vigour Index. Length $=\mathrm{cm}$, Weight $=m g$

\section{References}

Bashan Y, Holguin G (1998) Proposal for the division of plant growth-promoting rhizobacteria into two classifications: biocontrol-PGPB (plant growth-promoting bacteria) and PGPB. Soil Biology \& Biochemistry 30: 1225-1228.

Bhardwaj G, Shah R, Joshi B, Patel P (2017) Klebsiella pneumoniae VRE36 as a PGPR isolated from Saccharum officinarum cultivar Co99004. Journal of Applied Biology and Biotechnology 5: 047-052.

Brown AE, Hamilton J (1992) Indole-3-ethanol produced by Zygorrhynchus moelleri, an indole-3-acetic acid analogue with antifungal activity. Mycological Research 96: 71-74.

Cappuccino JGS, Cappuccino NJG, Sherman N (1996) Microbiology: a laboratory manual. Rockland Community College, Pearson.

Chaiharn M, Chunhaleuchanon S, Kozo A, Lumyong S (2008) Screening of rhizobacteria for their plant growth promoting activities. KMITL Science and Technology Journal 8: 18-23.

Datta C, Basu P (2000) Indole acetic acid production by a Rhizobium species from root nodules of a leguminous shrub, Cajanus cajan. Microbiological Research 155: 123-127.

Deepa CK, Dastager Syed G, Pandey A (2010) Isolation and characterization of plant growth promoting bacteria from nonrhizospheric soil and their effect on cowpea (Vigna unguiculata (L.) Walp.) seedling growth. World Journal of Microbiology and Biotechnology 26: 1233-1240.
Egamberdiyeva D (2007) The effect of plant growth promoting bacteria on growth and nutrient uptake of maize in two different soils. Applied Soil Ecology 36: 184-189.

Felsenstein J (1985) Confidence limits on phylogenies: an approach using the bootstrap. International Journal of Organic Evolution 39: 783-791.

Gulati A, Vyas P, Rahi P, Kasana RC (2009) Plant growthpromoting and rhizosphere-competent Acinetobacter rhizosphaerae strain BIHB 723 from the cold deserts of the Himalayas. Current Microbiology 58: 371-377.

Haas D, Défago G (2005) Biological control of soil-borne pathogens by Fluorescent pseudomonads. Nature Reviews Microbiology 3: 307-319.

Hahn K, Strittmatter G (1994) Pathogen-Defence Gene prp1-1 from Potato Encodes an Auxin-Responsive Glutathione S-Transferase. European Journal of Biochemistry 226 :619-626.

Huddedar S, Shete A, Tilekar J, Gore S, Dhavale D, Chopade B (2002) Isolation, characterization, and plasmid pUPI126-mediated indole-3-acetic acid production in Acinetobacter strains from rhizosphere of wheat. Applied Biochemestry and Biotechnology 102: 21-39.

Indiragandhi P, Anandham R, Madhaiyan M, Sa TM (2008) Characterization of plant growth-promoting traits of bacteria isolated from larval guts of diamondback moth Plutella xylostella (Lepidoptera: Plutellidae). Current Microbiology 56: 327-333.

Jensen H (1965) Nonsymbiotic nitrogen fixation. Soil nitrogen: 436-480. 
Jones DL, Darrah PR (1994) Role of root derived organic acids in the mobilization of nutrients from the rhizosphere. Plant soil 166: 247-257.

Kimura M (1980) A simple method for estimating evolutionary rates of base substitutions through comparative studies of nucleotide sequences. Journal of Molecular Evolution 16: 111120 .

Kuan KB, Othman R, Rahim KA, Shamsuddin ZH (2016) Plant growth-promoting rhizobacteria inoculation to enhance vegetative growth, nitrogen fixation and nitrogen remobilisation of maize under greenhouse conditions. PloS one 11:e0152478.

Lamy B, Laurent F, Verdier I, Decousser JW, Lecaillon E, Marchandin H, Roger F, Tigaud S, de Montclos H, Kodjo A (2010) Accuracy of 6 commercial systems for identifying clinical Aeromonas isolates. Diagnostic Microbiology and Infectious Disease 67: 9-14.

Lytvynenko T, Zaetz I, T Voznyuk, Kovalchuk M, Rogutsky I, Mytrokhyn O, Lukashov D, Estrella-Liopis V, Borodinova T, Mashkovska S (2006) A rationally assembled microbial community for growing Tagetes patula $L$. in a lunar greenhouse. Research Microbiology 157: 87-92.

Mendes R, Garbeva P, Raaijmakers JM (2013) The rhizosphere microbiome: significance of plant beneficial, plant pathogenic, and human pathogenic microorganisms. FEMS Microbiology Reviews 37: 634-663.

Modi K, Patel P (2017) Isolation and Characterization of Plant Growth Promoting Rhizobacteria Associated with Saccharum officinarum L. Current Synthetic and System Biology 5:32-37.

Mohanraj D, Padmanaban P, Viswanathan R (2002) Biological control of sugarcane diseases. S. Gnanamanikkam, Marcel Dekkar Inc., New York: 161-177.

Patten CL, Glick BR (2002a) Regulation of indoleacetic acid production in Pseudomonas putida GR12-2 by tryptophan and the stationary-phase sigma factor RpoS. Canadian Journal of Microbiology 48: 635-642.

Patten CL, Glick BR (2002b) Role of Pseudomonas putida indoleacetic acid in development of the host plant root system. Applied and Environmental Microbiology 68: 3795-3801.

Peix A, Lang E, Verbarg S, Spröer C, Rivas R, Santa-Regina I, Mateos PF, Martínez-Molina E, Rodríguez-Barrueco C, Velázquez E (2009) Acinetobacter strains IH9 and OCI1, two rhizospheric phosphate solubilizing isolates able to promote plant growth, constitute a new genomovar of Acinetobacter calcoaceticus. Systematic and Applied Microbiology 32: 334-341.

Pikovskaya R (1948) Mobilization of phosphorus in soil in connection with vital activity of some microbial species. Mikrobiologiya 17:e370.

Razmi Z, Hamidi R, Pirasteh-Anosheh H (2013) Seed germination and seedling growth of three sorghum (Sorghum bicolor L.) genotypes as affected by low temperatures. International Journal of Farming and Allied Sciences 2: 851-856.

Reed M, BG Warner, BR Glick (2005) Plant Growth-Promoting Bacteria Facilitate the Growth of the Common Reed Phragmites australisin the Presence of Copper or Polycyclic Aromatic Hydrocarbons. Current Microbiology 51: 425-429.

Rokhbakhsh-Zamin F, Sachdev D, Kazemi-Pour N, Engineer A, Pardesi KR, Zinjarde S, Dhakephalkar PK, Chopade BA (2011) Characterization of plant-growth-promoting traits of Acinetobacter species isolated from rhizosphere of Pennisetum glaucum. Journal of Microbiology and Biotechnology 21: 556566.

Sachdev D, Nema P, Dhakephalkar P, Zinjarde S, Chopade B (2010) Assessment of 16S rRNA gene-based phylogenetic diversity and promising plant growth-promoting traits of Acinetobacter community from the rhizosphere of wheat. Microbiological Research 165: 627-638.

Saitou N, Nei M (1987) The neighbor-joining method: a new method for reconstructing phylogenetic trees. Molecular Biology and Evolution 4: 406-425.

Sarode Prashant D, Rane Makarand R, Chaudhari Bhushan L, Chincholkar Sudhir B (2009) Siderophoregenic Acinetobacter calcoaceticus isolated from wheat rhizosphere with strong PGPR activity. Malaysian Journal of Microbiology 5: 6-12.

Schwyn B, Neilands J (1987) Universal chemical assay for the detection and determination of siderophores. Analytical Biochemistry 160: 47-56.

Sharma A, Johri BN, Sharma AK, Glick BR (2003) Plant growthpromoting bacterium Pseudomonas sp. strain GRP 3 influences iron acquisition in mung bean (Vigna radiata L. Wilzeck). Soil Biology and Biochemistry 35:887-894.

Swain MR, Naskar SK, Ray RC (2007) Indole-3-acetic acid production and effect on sprouting of yam (Dioscorea rotundata 
L.) minisetts by Bacillus subtilis isolated from culturable cowdung microflora. Polish Journal of Microbiology 56: 103.

Tamura K, Peterson D, Peterson N, Stecher G, Nei M, Kumar S (2011) MEGA5: Molecular evolutionary genetics analysis using maximum likelihood, evolutionary distance, and maximum parsimony methods. Molecular Biology and Evolution. 28: 2731 2739.

Teixeira DA, Alfenas AC, Mafia RG, Ferreira EM, Siqueira L, Maffia LA, Mounteer AH (2007) Rhizobacterial promotion of eucalypt rooting and growth. Brazilian Journal of Microbiology 38: $118-123$

Toro M, Azcon R, Barea J (1997) Improvement of Arbuscular Mycorrhiza Development by Inoculation of Soil with PhosphateSolubilizing Rhizobacteria To Improve Rock Phosphate Bioavailability ((sup32) P) and Nutrient Cycling. Applied and Environmental Microbiology 63: 4408-4412.

Zablotowicz RM, Tipping EM, Lifshitz R, Kloepper JW (1991) Plant growth promotion mediated by bacterial rhizosphere colonizers. The Rhizosphere and Plant Growth 14: 315-326. 